Open Access

\title{
Retraction Note: Is it possible to control and optimize technology transfer process? \\ CrossMark
}

Stefano De Falco

\author{
Correspondence: sdefalco@unina.it \\ The online version of the original \\ article can be found under \\ doi:10.1186/2192-5372-1-6. \\ Technology Transfer Magazine, \\ Italian Association for Promotion of \\ Culture of Technology Transfer, \\ Technology Transfer Office, School \\ of Sciences and Technologies, \\ University of Naples, Federico II, Via \\ Cinthia, Naples 80 126, Italy
}

The Editor-in-Chief of the Journal of Innovation and Entrepreneurship retracts this article (De 2012) per the Committee on Publication Ethics (COPE) guidelines on plagiarism, due to unattributed use of substantial portions of text from the following article, by Shin, S. et al., Integrating the Lambert $W$ Function to a Tolerance Optimization Problem (Quality and Reliability Engineering International 2005; 21: 795-808; Wiley Inderscience, DOI: 10.1002/qre.687). The Editor-in-Chief takes issues of research and publication misconduct seriously in order to preserve the integrity of the academic record. Our apologies are extended to the readers that this issue was not discovered before publication.

Received: 13 May 2016 Accepted: 13 May 2016

Published online: 06 June 2016

Reference

De, F. (2012). Is it possible to control and optimize technology transfer process? Journal of Innovation and Entrepreneurship, 1, 6.
Submit your manuscript to a SpringerOpen ${ }^{\circ}$ journal and benefit from:

- Convenient online submission

Rigorous peer review

- Immediate publication on acceptance

- Open access: articles freely available online

- High visibility within the field

- Retaining the copyright to your article

Submit your next manuscript at $>$ springeropen.com 